\title{
Kendrick Mass Defect Variation to Decipher Isotopic Labeling in Brain Metastases Studied by Mass Spectrometry Imaging
}

Landry Blanc, ${ }^{*}$ Gino B. Ferraro, Michael Tuck, Brendan Prideaux, Véronique Dartois, Rakesh K. Jain, and Nicolas Desbenoit
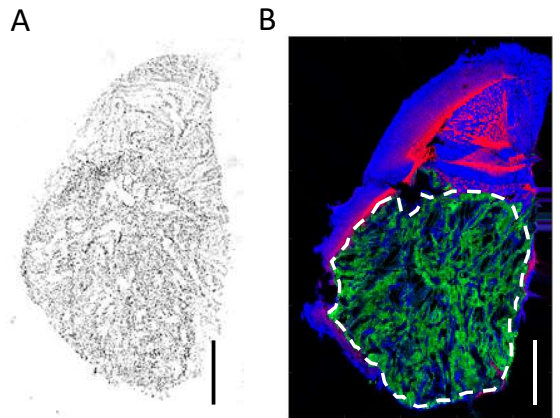

Mouse Brain - unlabeled
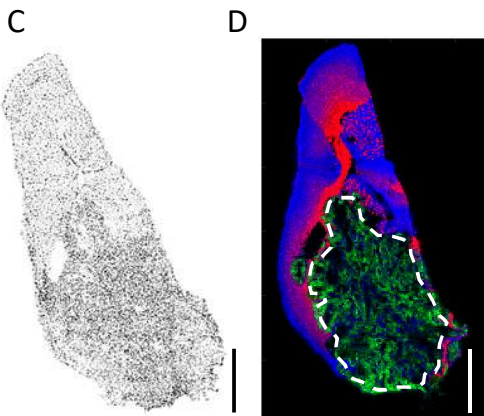

Mouse Brain $-{ }^{13} \mathrm{C}$-Glucose labeled
Figure S1 : Brain metastasis from ${ }^{13} \mathrm{C}$ Glucose labeled and unlabeled mice.

(A) DAPI staining of a brain tumor section from a unlabeled mouse. (scale bar, $1.5 \mathrm{~mm}$ ). (B) Serial sections MS imaging of associated brain tumor sections (C) DAPI staining of a brain tumor section from a ${ }^{13} \mathrm{C}$-Glucose labeled mouse. (D) Serial sections MS imaging of associated brain tumor sections. Blue $\mathrm{m} / \mathrm{z}$ 885.549 [PI(38-4)-H] $]^{-} ;$Red $\mathrm{m} / \mathrm{z} \quad 888.623$ [Sulfatide(d42:2)-H] ${ }^{-}$; Green $\mathrm{m} / \mathrm{z} 889.5792$ [PI(38-2)-H] . Annotations made with exact mass and Lipid Maps database

Dashed white line highlight tumor area. 